\title{
Cows' milk hypersensitivity: immediate and delayed onset clinical patterns
}

\author{
R P K FORD, D J HILL, AND C S HOSKING \\ Departments of Gastroenterology and Immunology, Royal Children's Hospital, Melbourne, Australia
}

SUMMARY The clinical patterns of adverse reactions to cows' milk were examined in 72 children with cows' milk hypersensitivity. Two main groups were found, according to the time of onset of the adverse reaction-immediate onset, within one hour of milk ingestion and delayed onset, after one hour. Children with immediate onset reactions usually had cutaneous manifestations, positive prick tests, raised $\mathrm{IgE}$ values, were atopic, and the reaction was provoked by only small amounts of milk. Children with delayed onset reactions usually had gastrointestinal manifestations; negative prick tests; normal IgE values; were not atopic; had a history of vomiting, diarrhoea, and colic in the first year of life; and a larger amount of milk was needed to provoke the adverse reaction. Placing affected children into one or other category should increase the reliability of interpreting milk prick tests and clinical findings.

Many clinical and immunological characteristics have been studied in children with cows' milk hypersensitivity but the results have been inconsistent. The main reasons for this seem to be inadequate diagnostic criteria, failure to distinguish between milk hypersensitivity and the many other types of milk intolerance, and an assumption that all children with milk hypersensitivity have a similar immunological basis to their adverse reaction.

In most previous reports, children with milk hypersensitivity have been regarded as a homogeneous group, although recently several authors have reported differences in clinical patterns of adverse reactions to milk depending on the time of onset of the reaction. The time elapsed between milk ingestion and the onset of symptoms has been used to divide reactions into immediate onset and delayed onset. The actual time chosen has varied from one hour, ${ }^{12}$ to two hours, ${ }^{34}$ and to four hours. ${ }^{5}$ The adverse reactions to milk in these two groups may be mediated by quite different immunological mechanisms. If it is assumed that the basis of adverse reactions is the same in all children, then otherwise sound observations may be interpreted as unreliable and the findings may therefore be misleading. We present data supporting the concept that there are important differences in the clinical patterns of cows' milk hypersensitivity.

Patients and methods

Seventy two children with cows' milk hyper- sensitivity were studied. Their ages ranged from 3 months to 10 years 7 months, mean age 18 months. There was a selection bias towards children with predominantly gastrointestinal manifestations and therefore this group of patients cannot be regarded as a representative sample. Information was collected by means of a precoded questionnaire and children were followed up for periods between 3 months and 4 years.

Definite or probable hypersensitivity. Hypersensitivity to milk was defined as definite or probable according to the criteria set down below.

\section{Definite hypersensitivity}

Children were considered to have definite hypersensitivity (a) when Goldman's criteria ${ }^{6}$ were met and if lactose intolerance and possible coincidental infections at the time of food challenge had been excluded; (b) if there were life threatening symptoms after food ingestion and two or more such episodes had occurred; and (c) if a double blind challenge test was positive.

\section{Probable hypersensitivity}

Children were considered to have probable hypersensitivity (a) when only two challenges were positive or when adverse symptoms varied, although related to food ingestion, with challenges; and (b) if there were life threatening symptoms but only one such episode had occurred. 
As there were no important differences between these two groups, for further analysis children in both categories were considered to have milk hypersensitivity.

Milk challenges. Two types of food challenge were performed-double blind and open challenges. Children remained on a diet free of milk and any other foods suspected of causing adverse reactions for at least one week, and usually more than four weeks, before and also during the challenge period. Baseline symptoms were recorded for the week before challenges.

The double blind challenge was performed as previously described. ${ }^{7}$ Briefly, using $100 \mathrm{ml}$ of milk disguised with a soy formula (Prosobee Liquid, Mead-Johnson) and placebo drinks of soy, three milk challenges were given over an 11 day period interspersed with 8 placebo days. The first challenge was performed under single blind conditions in hospital with the volume increased slowly over a four hour period until symptoms developed or the whole drink had been taken. This volume was then used for the subsequent days. A double blind challenge was considered positive if (a) on the single blind challenge the child displayed such severe symptoms (laryngeal oedema, angioedema, protracted vomiting) that it was thought dangerous to continue the trial, or (b) during the double blind challenge the child showed such severe symptoms (vomiting, choking, angioedema) as to make it unwise to continue the trial, or (c) on completion of the double blind challenge regimen the child showed at least two symptoms (skin rash, angioedema, choking, coughing, vomiting, abdominal pain, diarrhoea, wheezing) on challenge days over and above the symptoms reported on placebo days.

Open challenges were begun in hospital with up to $100 \mathrm{ml}$ of fresh homogenised cows' milk. Between 1 and $5 \mathrm{ml}$ of milk was given initially, depending on the child's likely clinical sensitivity. Increasing amounts were then given over a two hour period until either symptoms occurred or the whole drink had been taken. The child remained under close observation for four hours or longer. If no symptoms or only a mild reaction occurred, the child was sent home with increasing amounts of milk to be taken at home. The parents kept a precoded diary describing symptoms and other details on each day of the challenge. The challenge was continued until symptoms developed or for four weeks, whichever was the shorter. A food challenge was considered positive if definite symptoms occurred that were in keeping with the child's history of food hypersensitivity, and which were not thought to be caused by other factors such as lactose intolerance or coincidental infections.

Skin tests. Skin prick tests were done with Bencard allergens to a control solution (whole cows' milk (5202) and whole hen's egg (5201)) on the patient's back with 1-2 cm separation between tests. The prick was made with a 23 gauge needle. No skin sterilant was used. Wheals were measured with a Bencard Skin Reaction Gauge, a transparent plastic square with circles of specified diameter. Measurements were made to the nearest $\mathrm{mm}$ at 10 and 20 minutes and the largest diameter was recorded. The result was disregarded if antihistamines had been taken within a 48 hour period and if the histamine control wheal was less than $2 \mathrm{~mm}$ diameter. The prick test was defined as positive if the wheal diameter was $3 \mathrm{~mm}$ or greater.

The data were analysed using the Statistical Package for Social Scientists (SPSS, Macraw Hill) with statistical significance determined by $\chi^{2}$ tests or correlation coefficients.

\section{Results \\ Manifestations.}

\section{Time of onset}

The time of onset of adverse reactions was defined as immediate if the first symptoms occurred within one hour of milk ingestion, and delayed if the first symptoms occurred after one hour. When the types of symptoms were examined in relation to time of onset of the reaction, two main groups emerged (Table 1). Children with cutaneous reactions had predominantly immediate onset reactions $(P=0.0001$, $\chi^{2}$ squared from two by two tables) while children with gastrointestinal reactions had mainly delayed onset reactions $(P=0.008)$. Of the gastrointestinal symptoms, abdominal pain $(P=0.035)$ and diarrhoea $(P=0.081)$ were associated with delayed onset late reactions, while vomiting occurred with both immediate and delayed onset groups $(P=0 \cdot 61)$. Respiratory symptoms $(\mathrm{P}=\mathbf{0} \cdot 14)$ and irritability $(P=0.54)$ also occurred with both types of reaction.

\section{Milk skin prick test}

When the types of symptoms manifest were analysed in relation to the result of milk skin prick tests, the same two main groups emerged (Table 2). Children with positive milk prick tests usually had cutaneous symptoms $(P=0.002)$ while those with negative prick tests usually had gastrointestinal symptoms $(P=0.006)$. Again diarrhoea $(P=0.0037)$ and abdominal pain $(\mathrm{P}=0.004)$ were associated with negative prick tests, while vomiting $(P=0.59)$, 
Table 1 Symptoms of children with milk hypersensitivity $v$ time of onset

\begin{tabular}{|c|c|c|c|c|c|}
\hline \multirow{3}{*}{$\begin{array}{l}\text { Symptoms } \\
\text { Cutaneous }\end{array}$} & \multicolumn{4}{|c|}{ Time of onset of reaction } & \multirow{3}{*}{$\begin{array}{l}\begin{array}{l}P \text { value } \\
\left(\chi^{2} \text { test }\right)\end{array} \\
0.0001\end{array}$} \\
\hline & \multicolumn{2}{|c|}{$\begin{array}{l}\text { Immediate } \\
(n=32(46 \%)) \\
\text { No }(\%)\end{array}$} & \multicolumn{2}{|c|}{$\begin{array}{l}\text { Delayed } \\
(n=37(54 \%)) \\
\text { No }(\%)\end{array}$} & \\
\hline & 26 & (72) & 10 & (28) & \\
\hline Angioedema & 16 & (84) & 3 & (16) & 0.0003 \\
\hline Macular rash & 18 & (75) & 6 & (25) & 0.001 \\
\hline Urticaria & 9 & (82) & 2 & (18) & 0.025 \\
\hline Eczema & & (60) & 6 & (40) & 0.37 \\
\hline Gastrointestinal & 23 & (39) & 36 & $(61)$ & 0.008 \\
\hline Vomiting & 17 & (43) & 23 & (57) & 0.61 \\
\hline Diarrhoea & & (36) & 25 & (64) & 0.081 \\
\hline $\begin{array}{l}\text { Colic, abdominal } \\
\text { pain }\end{array}$ & 10 & (31) & 22 & $(69)$ & 0.035 \\
\hline Respiratory & 16 & (59) & 11 & (41) & $0 \cdot 14$ \\
\hline Coughing, choking & 5 & (50) & 5 & (50) & 0.99 \\
\hline Wheezing & 10 & (71) & 4 & (29) & 0.07 \\
\hline Allergic rhinitis & 10 & (56) & 8 & (44) & 0.53 \\
\hline \multicolumn{6}{|l|}{ Other } \\
\hline Irritability & 14 & (41) & 20 & (59) & 0.54 \\
\hline Pallor & 4 & (40) & 6 & (60) & \\
\hline Limp, unconscious & 1 & (33) & 2 & (67) & \\
\hline Lethargy & 2 & (67) & 1 & (33) & \\
\hline $\begin{array}{l}\text { Screaming, } \\
\text { sleep disturbance }\end{array}$ & & & & & \\
\hline $\begin{array}{l}\text { sleep disturbance } \\
\text { Sore mouth }\end{array}$ & $\begin{array}{l}0 \\
1\end{array}$ & & $\begin{array}{l}5 \\
0\end{array}$ & $(100)$ & \\
\hline $\begin{array}{l}\text { Sore mouth } \\
\text { Infraorbital rings }\end{array}$ & $\begin{array}{l}1 \\
0\end{array}$ & $(100)$ & $\begin{array}{l}0 \\
0\end{array}$ & & \\
\hline \multicolumn{6}{|l|}{ Associations } \\
\hline \multicolumn{6}{|l|}{$\begin{array}{c}\text { Positive milk } \\
\text { prick test }\end{array}$} \\
\hline $\begin{array}{l}\text { prick test } \\
\text { Positive milk RAST }\end{array}$ & 20 & (77) & 6 & (23) & 0.0001 \\
\hline Positive milk RAST & 8 & $(80)$ & 2 & (20) & 0.017 \\
\hline \multicolumn{6}{|l|}{ Positive egg } \\
\hline Positive egg RAST & $\begin{array}{r}21 \\
7\end{array}$ & $\begin{array}{l}(75) \\
(58)\end{array}$ & 5 & (42) & 0.32 \\
\hline $\begin{array}{l}\text { POSitive egg KAS1 } \\
\text { Atopic }\end{array}$ & $\begin{array}{r}7 \\
22\end{array}$ & $\begin{array}{l}(58) \\
(60)\end{array}$ & 15 & $(40)$ & 0.036 \\
\hline \multicolumn{6}{|l|}{ Positive inhalant } \\
\hline prick tests & 17 & (61) & 11 & (39) & 0.084 \\
\hline Raised IgE & 5 & (56) & 4 & (44) & 0.43 \\
\hline \multicolumn{6}{|c|}{ Immedite family history of } \\
\hline Allergy & 25 & (47) & 28 & (53) & 0.99 \\
\hline \multicolumn{6}{|l|}{ Milk } \\
\hline hypersensitivity & 6 & (46) & 7 & (54) & 0.99 \\
\hline
\end{tabular}

RAST $=$ radioallergosorbent test.

respiratory symptoms $(P=0.99)$, and irritability $(P=0 \cdot 13)$ occurred in both prick test positive and negative groups.

\section{Relation between time of onset and milk prick test result}

There was a highly significant positive correlation between the time of onset of the clinical reaction and the result of the milk prick test, $\mathrm{r}=0.50(\mathrm{P}=0.0001)$. An immediate onset reaction was associated with a positive milk prick test. To determine if there were any major effects on this correlation, the partial correlations were calculated while statistically controlling for the major influencing factors-the presence of gastrointestinal symptoms, cutaneous symptoms, and atopy. This showed that the correlation between time of onset and the results of the
Table 2 Symptoms of children with milk hypersensitivity $v$ milk prick test result

\begin{tabular}{|c|c|c|c|c|c|}
\hline \multirow{2}{*}{$\begin{array}{l}\text { Symptoms } \\
\text { Cutaneous }\end{array}$} & \multicolumn{4}{|c|}{ Milk skin prick test response } & \multirow{2}{*}{$\begin{array}{l}\begin{array}{l}P \text { value } \\
\left(\chi^{2} \text { test }\right)\end{array} \\
0.0002\end{array}$} \\
\hline & \multicolumn{2}{|c|}{$\begin{array}{l}\text { Positive } \\
(n=28(40 \%)) \\
\text { No }(\%)\end{array}$} & \multicolumn{2}{|c|}{$\begin{array}{l}\text { Negative } \\
(n=42(60 \%)) \\
\text { No }(\%)\end{array}$} & \\
\hline $\begin{array}{l}\text { Cutaneous } \\
\text { Angioedema } \\
\text { Macular rash } \\
\text { Urticaria } \\
\text { Eczema }\end{array}$ & $\begin{array}{r}23 \\
14 \\
15 \\
7 \\
10\end{array}$ & $\begin{array}{l}(62) \\
(70) \\
(63) \\
(70) \\
(62)\end{array}$ & $\begin{array}{r}14 \\
6 \\
9 \\
3 \\
6\end{array}$ & $\begin{array}{l}(38) \\
(30) \\
(37) \\
(30) \\
(38)\end{array}$ & $\begin{array}{l}0.0002 \\
0.003 \\
0.012 \\
0.081 \\
0.07\end{array}$ \\
\hline $\begin{array}{l}\text { Gastrointestinal } \\
\text { Vomiting } \\
\text { Diarrhoea } \\
\text { Colic, abdominal } \\
\text { pain }\end{array}$ & $\begin{array}{r}19 \\
14 \\
9\end{array}$ & $\begin{array}{l}(32) \\
(36) \\
(23)\end{array}$ & $\begin{array}{l}40 \\
25 \\
30\end{array}$ & $\begin{array}{l}(68) \\
(64) \\
(77)\end{array}$ & $\begin{array}{l}0.006 \\
0.59 \\
0.0027\end{array}$ \\
\hline $\begin{array}{l}\text { Respiratory } \\
\text { Coughing, choking } \\
\text { Wheezing } \\
\text { Allergic rhinitis }\end{array}$ & $\begin{array}{r}11 \\
4 \\
7 \\
7\end{array}$ & $\begin{array}{l}(41) \\
(40) \\
(50) \\
(39)\end{array}$ & $\begin{array}{r}16 \\
6 \\
7 \\
11\end{array}$ & $\begin{array}{l}(59) \\
(60) \\
(50) \\
(61)\end{array}$ & $\begin{array}{l}0.99 \\
0.99 \\
0.58 \\
0.99\end{array}$ \\
\hline $\begin{array}{l}\text { Other } \\
\text { Irritability } \\
\text { Pallor } \\
\text { Limp, unconscious } \\
\text { Lethargy } \\
\text { Screaming, } \\
\text { sleep disturbance } \\
\text { Sore mouth } \\
\text { Infraorbital rings }\end{array}$ & $\begin{array}{r}10 \\
3 \\
1 \\
1\end{array}$ & $\begin{array}{l}(29) \\
(30) \\
(50) \\
(67)\end{array}$ & $\begin{array}{r}24 \\
7 \\
1 \\
2\end{array}$ & $\begin{array}{l}(71) \\
(70) \\
(50) \\
(33) \\
(100)\end{array}$ & 0.13 \\
\hline \multicolumn{6}{|l|}{ Associations } \\
\hline $\begin{array}{l}\text { Immediate onset } \\
\text { Positive milk RAST } \\
\text { Positive egg RAST } \\
\text { Positive egg }\end{array}$ & $\begin{array}{r}20 \\
11 \\
9\end{array}$ & $\begin{array}{l}(65) \\
(100) \\
(64)\end{array}$ & $\begin{array}{r}11 \\
0 \\
5\end{array}$ & $\begin{array}{l}(35) \\
(36)\end{array}$ & $\begin{array}{l}0.0001 \\
0.0001 \\
0.015\end{array}$ \\
\hline $\begin{array}{l}\text { prick test } \\
\text { Atopic } \\
\text { Positive inhalant }\end{array}$ & $\begin{array}{l}22 \\
21\end{array}$ & $\begin{array}{l}(76) \\
(51)\end{array}$ & $\begin{array}{l}10 \\
20\end{array}$ & $\begin{array}{l}(23) \\
(49)\end{array}$ & $\begin{array}{l}0.0001 \\
0.053\end{array}$ \\
\hline $\begin{array}{l}\text { prick test } \\
\text { Raised IgE }\end{array}$ & $\begin{array}{r}19 \\
7\end{array}$ & $\begin{array}{l}(66) \\
(70)\end{array}$ & $\begin{array}{r}10 \\
3\end{array}$ & $\begin{array}{l}(34) \\
(30)\end{array}$ & $\begin{array}{l}0.0008 \\
0.023\end{array}$ \\
\hline $\begin{array}{l}\text { Immediate family his } \\
\text { Allergy } \\
\text { Milk } \\
\text { hypersensitivity }\end{array}$ & $\begin{array}{c}25 \\
6\end{array}$ & $(45)$ & 31 & $(55)$ & $0 \cdot 26$ \\
\hline
\end{tabular}

milk prick test remained significant when controlled for all three factors, falling from $r=0 \cdot 50(P=0.0001)$ to $r=0.28 \quad(P=0.011)$. The largest effect on this correlation was the presence of cutaneous manifestations.

\section{Discriminant analysis.}

The validity of dividing children with milk hypersensitivity into those who had immediate or delayed onset reactions was further tested by discriminant analysis. This analysis was done in three separate ways using clinical history, investigative tests, and the combination of history and investigations. This analysis confirmed that children with milk hypersensitivity had different clinical characteristics depending on the time of onset of the adverse reactions. 


\section{Clinical history}

The following aspects of clinical history were examined: the type of symptoms (angioedema, macular rash, urticaria, eczema, vomiting, diarrhoea, abdominal pain and colic, respiratory symptoms, and irritability); the age of onset of milk hypersensitivity; the volume of milk causing a reaction; the length of breast feeding; the age of introduction of cows' milk; the presence of atopy; a history of other food hypersensitivity; an immediate family history of allergy; and an immediate family history of milk hypersensitivity. Discriminant analysis showed that only 8 variables (macular rash, other food hypersensitivity, atopy, angioedema, irritability, amount of milk, eczema, and abdominal pain) were important in predicting the likely time of onset of the adverse reaction. With this analysis $86 \%$ of the children were grouped correctly with a canonical correlation $r=0.69(P=0.00001)$. See Figure.

\section{Investigations}

The following investigations were examined: results of skin prick tests to milk, egg, and inhalant allergens; radioallergosorbent test (RAST) to milk; immunoglobulin values; and the eosinophil count. Discriminant analysis found that only two of these variables (milk prick test and eosinophil count) could correctly group $64 \%$ of the children, with the other variables being non-contributory. When the results of skin prick tests results alone were examined, only $49 \%$ could be grouped correctly by using the results of the egg and inhalant prick tests.

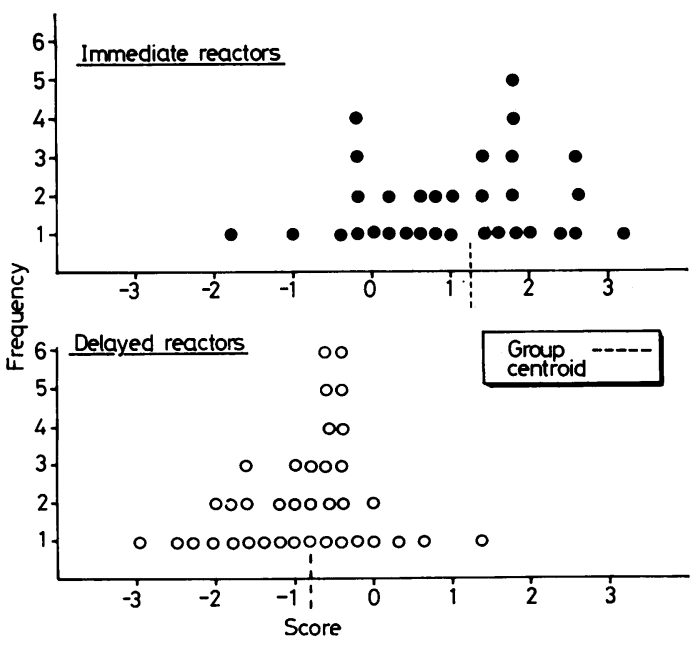

Figure Discriminant analysis of immediate and delayed milk hypersensitivity reactions using clinical history.

\section{History and investigations}

When both clinical history and skin prick test results were examined together the skin prick tests did not contribute in any way to the accuracy of grouping into immediate and delayed onset groups, and so were excluded in the discriminant analysis function.

Other associations. Other associations were found with milk hypersensitivity related to the time of onset of the reaction and milk prick test responses in Tables 1 and 2.

\section{Prick tests}

Positive egg prick tests were found in significantly more children with immediate onset reactions $(P=0.0001)$ or with positive milk prick tests $(\mathbf{P}=\mathbf{0 . 0 0 0 1 )}$ than in those with delayed onset reactions or negative milk prick tests; an association of the same order as for milk prick tests. Inhalant prick tests were more frequently positive in the milk prick test positive group $(P=0 \cdot 0008)$.

\section{Atopy}

Atopic children were more likely to have immediate onset reactions $(P=0.036)$ and positive milk prick tests $(P=0.053)$. This was particularly so for asthma, as 19 of the $32(59 \%)$ children with immediate onset reactions had a history of wheezing compared with 10 of $37(27 \%)$ in the delayed onset group $(P=0.015)$. There were similar figures for the incidence of asthma in the milk prick test groups.

\section{Family history of allergy}

There was no association of either immediate or remote family history of allergy or milk hypersensitivity with the time of onset of the reactions or results of the milk prick test.

\section{Gastrointestinal symptoms in the first year of life}

Vomiting $(P=0.004)$, diarrhoea $(P=0.0007)$, and colic $(P=0.025)$ were found more frequently during the first year of life in children with negative milk prick tests. Also, diarrhoea $(P=0.026)$ and colic $(P=0.013)$ were found more frequently in children with delayed onset than those with immediate reactions.

\section{Dietary history}

There were no differences between the two groups in relation to the length of time of breast feeding, the giving of colostrum, the amount of dairy products ingested by the mother while breast feeding, and the timing of introduction of cows' milk protein into the infant's diet. 


\section{Immunoglobulins}

Children with positive milk prick tests had significantly higher total serum $\operatorname{IgE}$ values $(P=0 \cdot 023)$ than those with negative milk prick tests.

\section{Natural history}

The children with milk hypersensitivity were followed up for periods of between 3 months and 3 years 9 months. Their age at enrolment ranged from 3 months to 6 years 10 months (mean, 1 year 6 months), and their ages at final follow up ranged from 10 months to 10 years 1 month (mean, 3 years 3 months).

Cows' milk formula was introduced into their diets in $41(58 \%)$ by the first weeks of life, in 46 $(65 \%)$ by 3 months, and in $65(93 \%)$ by 6 months. Clinical hypersensitivity reactions were experienced by these children at the first apparent exposure to cows' milk in $22(33 \%)$, at its reintroduction after breast feeding in $25(36 \%)$, and at subsequent milk feeds in $23(33 \%)$.

Children who did not react to milk at their first exposure had milk introduced into their diet within the first four weeks of life much more frequently than children who did react at their first exposure $\left(\mathbf{P}=\mathbf{0} \cdot 004, \chi^{2}\right.$ test $)$. This suggests that children with late introduction of cows' milk were sensitised to cows' milk via breast milk. No relation was found between reactions at first exposure to cows' milk and the time of onset of the reaction $(P=0.99)$ or the response to milk prick tests $(P=0 \cdot 21)$.

The 70 children were divided into two groups according to whether or not they had developed clinical tolerance to milk by the time of the final follow up (Table 3). From the frequency distribution patterns the children with resolved milk hypersensitivity seemed to be older than those in whom it persisted. This indicated that the major factor determining the development of clinical tolerance to milk was the age of the child. In those children who had developed clinical tolerance to milk, no factors

Table 3 Ages at follow up of children with resolved and persisting milk hypersensitivity

\begin{tabular}{lllll}
\hline $\begin{array}{l}\text { Age group } \\
\text { at follow } \\
\text { up (years) }\end{array}$ & $\begin{array}{l}\text { Resolved } \\
\text { hypersensitivity } \\
\text { patients } \\
(n=48) \\
\text { No }(\%)\end{array}$ & $\begin{array}{l}\text { Cumulative } \\
\text { percentage }\end{array}$ & $\begin{array}{l}\text { Persisting } \\
\text { hypersensitivity } \\
\text { patients } \\
(n=24)\end{array}$ & $\begin{array}{l}\text { Cumulative } \\
\text { percentage }\end{array}$ \\
\hline $0-1$ & $6(13)$ & 13 & $9(38)$ & \\
$1-2$ & $17(36)$ & 49 & $6(24)$ & 38 \\
$2-3$ & $12(25)$ & 74 & $4(17)$ & 63 \\
$3-4$ & $5(10)$ & 84 & $4(17)$ & 79 \\
$4-5$ & $4(8)$ & 92 & $1(4)$ & 106 \\
$5-6$ & $1(2)$ & 94 & $0(0)$ & 100 \\
$6+$ & $3(6)$ & 100 & $0(0)$ & 100 \\
\hline
\end{tabular}

were found to indicate the age at which resolution of milk hypersensitivity might occur. The factors examined were the time of onset of the reaction, the response to milk prick tests, the age of onset of milk hypersensitivity, the type of symptoms manifest, and the dietary history.

\section{Discussion}

From this study, two distinct clinical patterns have emerged. Immediate onset reactions were defined as occurring within one hour of food ingestion, and delayed onset reactions after one hour. Some immediate type 1 reactions may have occurred after one hour but, because of the data collection methods, analysis of clinical groupings using $1 \frac{1}{2}$ and 2 hour times as dividing criteria was not possible. Analysis at four hours of elapsed time did not distinguish between the two groups as well as at one hour.

There is almost certainly some overlap in the elapsed times between these two patterns of clinical reaction. The time of onset may be altered to some extent by the age of the child, the amount of food given, the speed with which the food is taken, the degree of sensitisation to that food, and the types of responding immunological mechanisms.

Children with immediate onset reactions to milk had predominantly cutaneous manifestations (particularly macular rashes, angioedema and urticaria) associated with positive milk prick tests. They also were likely to have positive prick test responses to egg and inhalant allergens, positive RASTs to milk and egg, and atopic illness (particularly eczema and asthma). Children with delayed onset reactions to milk had predominantly gastrointestinal manifestations with negative milk prick tests. They had correspondingly negative RAST responses to milk and were usually non-atopic. They also frequently had a history of colic, vomiting, and diarrhoea in the first year of life. These findings confirm the similar clinical groups reported by Dannaeus and Johansson. ${ }^{1}$

There were no differences between these two groups in dietary history, the age of onset and resolution of milk hypersensitivity, and an immediate family history of allergy. Both groups developed vomiting and respiratory symptoms with milk challenge with the same frequency.

This grouping into clinical patterns depending on the time of onset has implications in terms of the immunological mechanisms likely to be affected. The evidence suggests that the immediate onset reactions are mediated by $I g E$ type 1 reactions, as these children had positive prick test and RAST responses indicating specific IgE sensitisation, and 
they also had atopic illness and raised total IgE values. It has been shown that specific IgE can be produced locally in the nasal mucosa in adults with allergic rhinitis caused by house dust mite, despite the findings of negative prick test and RAST responses in these patients. ${ }^{8}$ This local mucosal specific IgE production is a possible mechanism by which to explain a negative prick test in children with predominantly gastrointestinal reactions, although immediate onset reactions would be expected. Small bowel mucosal IgE reaction has been implicated by several investigators ${ }^{9-11}$ from observations of increased numbers of IgE producing plasma cells in the lamina propria of small bowel biopsies taken after milk challenge. But the reaction time in these children was several hours or days after milk ingestion. A possible explanation of this delayed reaction time is that the mucosal IgE response might enhance antigen absorption thus stimulating other immune responses.

The delayed onset reaction group did not show evidence of specific IgE production, and so type 3 and type 4 Gell and Coombs's reactions ${ }^{12}$ are likely candidates as the immunological mechanisms. Circulating immune complexes (antigen antibody complexes) of bovine proteins as antigen, and IgG as antibody, have been detected in most neonates fed with cows' milk, ${ }^{13}$ and in normal and atopic adults. ${ }^{14}$ Immune complexes may have an important role in mediating delayed onset hypersensitivity food reactions. Cell mediated or delayed hypersensitivity reactions to milk proteins have been shown more frequently in the serum of children with delayed onset food reactions than in children with immediate onset reactions. ${ }^{415}$ But responses to delayed hypersensitivity tests have also been positive in many normal asymptomatic controls. So, as yet, these tests lack both reliability and specificity. Patch testing has not been properly evaluated in the diagnosis of delayed food hypersensitivity reactions, but may prove a useful tool.

The group of children with delayed onset gastrointestinal reactions to milk included those who could be regarded clinically as having cows' milk protein sensitive enteropathy, ${ }^{16}$ and indeed milk related mucosal damage was shown in several children by serial small bowel biopsy. Minford and colleagues, ${ }^{17}$ in a review of children with food hypersensitivity, also identified this group of patients with mainly gastrointestinal symptoms. They reported that these children were not atopic and implied that their adverse response to milk provocation occurred after one hour.

Reactions were experienced at what seemed to be the first exposure to milk in $31 \%$ of children. These children had had cows' milk introduced at a later stage than the children who did not react at their first exposure. Children with reactions at their first exposure may have been sensitised via breast milk. More than $80 \%$ of the children developed clinical tolerance to milk by four years of age. The age of developing clinical tolerance was not correlated with any of the factors examined. In particular, it was not related to the time of onset of the reactions, the milk prick test response, or the symptoms manifest.

Thus two distinct clinical patterns have been shown and may be distinguished according to the time of onset of the reaction: immediate onset reactions, occurring within one hour, with predominantly cutaneous manifestations associated with positive prick tests; and delayed onset reactions, occurring after one hour, usually with gastrointestinal symptoms and negative prick tests. Dividing children into one or other of these categories should increase the reliability of interpreting investigations and clinical findings.

This study was funded by the National Health and Medical Research Council (Australia), and the Canterbury Medical Research Foundation (New Zealand). We thank Dr G L Barnes and Dr B Taylor for their clinical guidance, Mr M J Shelton for computing assistance and Vivienne Mavriopoulos for typing the manuscript.

\section{References}

1 Dannaeus A, Johansson SGO. A follow-up study of infants with adverse reactions to cows' milk. 1. Serum IgE skin test reactions and RAST in relation to clinical course. Acta Paediatr Scand 1979;68:377-82.

2 Wraith DG, Merrett J, Roth A, Yman L, Merrett TG. Recognition of food-allergic patients and their allergens by the RAST technique and clinical investigation. Clin Allergy 1979;9:25-36.

3 Bock SA, Lee WY, Remigio L, May CD. Studies of hypersensitivity reactions to foods in infants and children. $J$ Allergy Clin Immunol 1978;62:327-34.

4 Minor JD, Tolber SG, Frick OL. Leukocyte inhibition factors in delayed-onset food allergy. $J$ Allergy Clin Immunol 1980;66:314-21.

5 Hill DJ, Davidson GP, Cameron DJS, Barnes GL. The spectrum of cows' milk allergy in childhood: clinical, gastroenterological and immunological studies. Acta Paediatr Scand 1979;68:847-52.

- Goldman AS, Anderson DW, Sellers WA, Saperstein S, Kniker WT, Halpern SR. Milk allergy I. Oral challenge with milk and isolated milk proteins in allergic children. Pediatrics $1963 ; 32: 425-43$.

7 Ford RPK, Fergusson DM. Egg and cows' milk allergy in children. Arch Dis Child 1980;55:608-10.

8 Huggins KG, Brostoff J. Local production of specific IgE antibodies in allergic rhinitis patients with negative skin tests. Lancet 1975 ;ii : 147-50.

9 Shiner M, Ballard J, Smith ME. The small-intestinal mucosa in cows' milk allergy. Lancet 1975 ; 1 :136-40.

10 Kilby A, Walker-Smith JA, Wood CBS. Small intestinal mucosa in cows' milk allergy (letter). Lancet $1975 ; \mathbf{i}: 531$.

11 Harris M, Petts V, Penny R. Cows' milk allergy as a cause of infantile colic: immunofluorescent studies on jejunal mucosa. Aust Paediatr J 1977;13:276-81. 
12 Gell PGH, Coombs RRA. Classification of allergic reactions. In: Gell RGH, Coombs RRA, eds. Clinical aspects of immunology. Oxford: Blackwell Scientific Publications, 1963.

13 Delire M, Cambiaso C, Masson PL. Circulating immune complexes in infants fed on cows' milk. Nature 1978; 272:632.

14 Paganelli R, Levinsky RJ, Brostoff J, Wraith DG. Immune complexes containing food proteins in normal and atopic subjects after oral challenge and effort of sodium cromoglycate on antigen absorption. Lancet $1979 ; \mathbf{i}: 1270-2$.

15 Ashkenazi A, Levin S, Idar D, Or A, Rosenberg I,
Handzel ZT. In vitro-cell mediated immunologic assay for cows' milk allergy. Pediatrics 1980:66:399-402.

16 Walker-Smith J, Harrison M, Kilby A, Phillips A, France N. Cows' milk-sensitive enteropathy. Arch Dis Child 1978;53:375-80.

17 Minford AMB, MacDonald A, Littlewood JM. Food intolerance and food allergy in children: a review of 68 cases. Arch Dis Child 1982;57:742-7.

Correspondence to Dr R P K Ford, Academic Department of Child Health, Queen Elizabeth Hospital for Children, Hackney Road, London E2 8PS.

Received 23 June 1983

\section{British Paediatric Association}

Annual meetings

1984 10-14 April York University

1985 16-20 April York University

1986 15-19 April York University

1987 7-11 April York University 